\title{
The Challenges of Training Policy in Project Environment: Case of Tunisia
}

\author{
Mohamed Ali Hedhili1 ${ }^{*}$ \\ Sami Boudabbous ${ }^{2}$ \\ 1,2 Department of Management, Faculty of Economics and Management, University of Sfax, \\ Tunisia.
}

\section{ARTICLE INFO}

ISSN: 2723-1097

Keywords:

Training policy, project environment, technical skills, interpersonal skills, Tunisia.

\begin{abstract}
Since the 1980s, the project has become an essential management approach for contemporary companies that require profound organizational transformations, hence the need for more in-depth studies on human resources development in this new environment. The present work aimed to recognize the different challenges of the training policy in the project environment. To this end, we conducted 31 semi-structured interviews with Tunisian project managers. The results showed that the training policy is a conducive context for skills development in the project environment. Project-based organizations are called upon to promote their employees' skills through training programs encompassing mainly two kinds of skills: interpersonal and technical. The results also revealed that the temporary and unstable nature of the projects leaves little room for training due to time pressure, lack of budget, and work overload.
\end{abstract}

\section{Introduction}

Since the 1980s, the organizational world has witnessed a dramatic evolution. Globalization and strong competition have pushed organizations to decline their functional structure based on the principles of scientific management and adopt new organizational forms to stand out in the business market. As a result, the project has become an essential management approach for contemporary companies that require deep organizational transformations (Huemann et al., 2007). In this context, the projects have to meet the changing requirements of the dynamic business environment through a new management model focused on results, technological advances, and satisfaction of specific customer demands (Söderlund and Bredin, 2006; Melkonian and Picq, 2011). Indeed, the projects are mainly spread across sectors in all fields of activity, such as construction, new technologies, research and development, etc. (Bartch et al., 2013; Prado and Sapsed, 2016; Munyeki and Were, 2017; Loufrani-Fedida, 2019).

Some previous research works have highlighted the need for further studies on the human resources development in the project environment (Söderlund and Bredin, 2006; Turner et al., 2008; Loufrani-Fedida and Saglietto, 2016; Keegan et al., 2018; Loufrani-Fedida, 2019; Samimi and Sydow, 2021). Koskinen (2009) argues that 
organizations need to acquire new skills to manage their projects successfully. Turner et al., (2008) state that human resource management practices that contribute to the project success are those that develop the specific skills and capacities of project actors.

The training policy plays a crucial role in building the skills that meet the project environment requirements (Bredin, 2008). Indeed, investment in human capital improves the productivity and performance of project actors (Małachowski and Korytkowski, 2016) and allows the individual to consolidate and improve his/ her skills portfolio. Indeed, few empirical studies have analyzed the training policy in the project environment (Tabassi and Bakar, 2009; Aramo-Immonen et al., 2011; Tabassi et al., 2012). This article aims to investigate the relationship between training policy and project environment in the Tunisian context. In other words, our goal was to provide answers to the following question: What are the challenges of the training policy in the project environment?

To answer this research question, we conducted 31 semi-structured interviews with Tunisian project managers of different profiles (gender, age, and years of experience). This article is divided into three parts. The first part is devoted to the literature review. The methodological elements of the research that are mobilized through a qualitative study are detailed in the second one. The third part presents the results of the research.

\section{Literature review}

\section{The emergence context of project}

Nowadays, the concept of the project has gained momentum in contemporary organizations (Loufrani-Fedida, 2019) and has become a prominent element in the sustainability of the company. For Turner and Keegan (2000), the project-based organization (PBO) has emerged as an innovative organizational structure that denounces the hierarchical structure based on the standardization of monotonous and repetitive tasks. The project resolves the complex operations of organizations and helps them adapt to rapid changes in the business environment (Melkonian and Picq, 2011).

Several factors have led companies to rationalize their management model, namely market globalization and competition, specific consumer demands, technology development (Project Management Institute, 2017) as well as organizational changes (Gemünden et al., 2018).

\section{Market globalization and competition}

Currently, the turbulent economic environment and the internationalization of trade have called into question mass production characterized by stable customer needs and little technological change (Turner and Keegan, 2000). Thus, companies have to adopt decentralized organizational structures, flexible production processes, and new management practices to face increasing competition. In this context, the PBO 
has developed as a flexible and innovative structure to perform complex operations (development of a new product, implementation of a new procedure, etc.) and to increase the pace of the production process (Čiutienè and Neverauskas, 2012). In order not to lose its market share, the company must promote the appropriate projects to gain competitive advantage, through the development of its products and services, and the transformation of its production process towards greater efficiency and responsiveness (Abrantes and Figueiredo, 2013). For these authors, the $\mathrm{PBO}$ is better adapted to a competitive market than a functional organization.

\section{Specific consumer demands}

Since the 1980s, market globalization and the intensity of competition have led companies to adopt new forms of adequate and flexible structures to respond to specific customer demands quickly (Hobday, 2000; Söderlund, 2005; Awuzie and McDermott, 2016; Munyeki and Were, 2017). In this context, companies are faced with increasingly demanding consumers who manifest different and transitory needs (Turner, 2016). According to Turner and Keegan (2000), the tasks of each unit of the organization change following the request of each customer. This results in better product quality through the optimal use of resources (Jamil and Magalhães, 2015). This new situation pushes companies to focus on the customer (Awuzie and McDermott, 2016), who has become "frequently closely and directly engaged in projects, as projects are critical to their business functioning, performance, and profitability" (Peltokorpi and Tsuyuki, 2006, p.38). For Gajic et al., (2014), the customer is a real actor in the development of the production process by participating in the negotiation of product quality criteria. Accordingly, customer satisfaction is highlighted in the PBO, as it plays an integral role in the project's success (Kujala and Ahola, 2005). Furthermore, the PBO must overcome traditional management methods and rethink its production process to increase its flexibility to new specific customer needs (Todorović et al., 2013).

\section{Technology development}

In the late 1970s, information and communication technologies experienced a real change of pace in a competitive and turbulent environment. Companies have to look for innovative ideas and reconsider their management methods (Bakker et al., 2013; Ben Taher and Launaro, 2018). They require the reconfiguration of resources and the adaptability of the project team to develop and maintain skills in new situations where technology is rapidly deployed (Davenprot, 2006). Indeed, new technologies help "reduce redundancy, minimize cost, integrate operations, and improve quality" (Al Marri, 2014, p.13). They present solutions to complex activities in companies that organize their operations into projects (Zohrevandi and Rouzbeh, 2014). The success of technological innovation requires a flexible structure that facilitates vertical and lateral communication between the project actors to solve problems. The project is, therefore, conceived as a response to technological developments. It must be able to improve "the organization's innovative capacity and potential" (Bresnen et al., 2003, p.158). 


\section{Organizational changes}

Following the economic and technological changes in the business environment, the emergence of PBOs seems to be linked to the structural crisis of the hierarchical organization for which it seeks to overcome a certain weakness (Defillipi and Lehrer, 2011). The PBO denounces the standardization of tasks, the lack of autonomy, and the strong centralization of decisions in favor of flexibility (Bakker, 2010; DeFillippi and Sydow, 2016; Gemünden et al., 2018). However, the transformation into a PBO can be achieved through two models (Bredin and Söderlund, 2006): First, the projectification which is a process through which companies modify and transform, over time, their structure, production process, and culture from a hierarchical and rigid organizational model to a project-based organizational structure. Second, the creation of new organizations that start as project-based structures from the very beginning.

In contrast to the functional structure, the $\mathrm{PBO}$ is a temporary structure in which human resources are brought together depending on projects (Genest and Nguyen, 2002; Choi et al., 2018). The project team will be disbanded at project closure and assigned to new projects. However, the project is presented as the primary unit of production that is independent of the rest of the parent organization (Hobday, 2000). Besides, the project manager, who has significant authority, has control over resources and responsibility for the success or failure of the project (Bocean, 2011). Furthermore, vertical communication between the manager and the project actors leads to a lack of opportunity for technical exchange and experience with other projects of the same parent organization. Undoubtedly, the PBO consists of supporting the flexibility of organizations (Bannerman et al., 2010) since it is designed to respond quickly to different business changes.

\section{Definitions of project}

Over the last few decades, projects have moved from traditional business management practices to a new management mode that is flexible and responsive to an organizational environment. However, the project has several definitions (Hedhili and Boudabbous, 2018; Leyrie, 2010).

The French approach related to the concept of the project is essentially based on the definition of the French-speaking Project Management Association (AFITEP). It defines a project as being "a specific approach that allows a future reality to be structured methodically and progressively. A project is defined and implemented to respond to a client's need (...), and it involves an objective and actions to be undertaken with given resources" (AFITEP-AFNOR, 2000, p.4). In 2002, AFITEP adopted the definition of ISO 10006 under the X50-105 documentation and provided a more comprehensive definition: "project is a unique process, consisting of a set of coordinated and controlled activities with start and finish dates, undertaken to achieve an objective conforming to specific requirements, including the constraints of time cost and resource". In the same vein, Genest and Nguyen (2002) present a similar definition: "a project is a complex set of tasks and activities that aim to produce and deliver a predetermined output within budget, due date(s), and quality constraints". 
According to the Anglo-Saxon literature, Turner (1993) defines the project as "an endeavor in which human, material, and financial resources are organized in a novel way, to undertake a unique scope of work, of given specification, within constraints of cost and time, so as to achieve beneficial change defined by quantitative and qualitative objectives".

By examining the definitions presented above, three major categories of project constraints can be identified (Garel et al., 2003): First, the technical specifications which correspond to a particular description of a product or a service to be carried out. They include the technical requirements of the product. Indeed, the project requires a level of quality that meets the customer's needs. However, when the project corresponds to a new product, the technical specifications must necessarily incorporate assumptions about the size of the potential market. Second, the deadline can be a major constraint for the project, as implementation contracts often have penalty clauses for late completion. Exceeding the predefined closing date may compromise the economic profitability of the project. Finally, cost control that corresponds to budgetary and financial constraints, such as the availability of the necessary skills, equipment, and technical requirements necessary for the execution of the project. These resources must take into account the objectives in terms of technical specificities and deadlines.

These three constraints must be coordinated from the very beginning of the project (Garel, 2003). Indeed, they "require rigorous coordination of technical, temporal, and economic piloting that involves the achievement of compromises between the different objectives of a project" (Loufrani-Fedida, 2006, p.97). Nevertheless, the project's success is not solely limited to saving time, reducing cost, and meeting quality standards but could be complemented by other factors, such as customer satisfaction and the constitution of multidisciplinary project teams (Cook and Pritchard, 1998).

\section{The training policy in project environment}

According to Loufrani-Fedida (2011), the training policy is considered an essential factor in human resources development. Researchers and industrial organizations have widely recognized the vital contribution of the training policy to modern organizations' success (Bredin, 2008). Training enables employees to acquire new skills that are essential for adapting to the new demands of the business environment (Loosmore et al., 2003; Cheng et al., 2006; Bredin, 2008; Tabassi et al., 2012).

Tabassi et al., (2012) present training as an important strategic element for the organization. Indeed, its correct use optimizes the organization's achievement (Chen and Huang, 2009) and facilitates the adaptation of employees to their social and professional environment. Also, the investment in human capital makes an important contribution to the overall performance of an organization (Lyons, 2009; Huemann, 2010; Zakaria, 2013), as systematic skills development is a key tool for improving the individual's productivity and performance ( $\mathrm{Ng}$ and Siu, 2004). Thus, training is essential for organizations to maintain their competitiveness (Salas and Cannon-Bowers, 2001). 
According to Zarifian (1988), training becomes the main medium that bridges the gap between current and required skill levels for the job profile. Therefore, the proper alignment between the training and the required skills allows the project actor to consolidate and increase his/ her skills portfolio to achieve effective performance in a given task or job (Clarke, 1999; Radović and Pejić, 2014). The training should target the specific development needs of the employee's work (Kiznyte et al., 2015) through job analysis, annual skills assessment, and organizational analysis (Othman et al., 2012). This enables the organization to plan regular training programs (Ochieng and Price, 2009; Shahzad, 2016) when the project actors do not have the necessary skills to meet the current tasks. Law and Chuah (2004) suggest a three-step approach for planning training programs, including (1) the identification of training objectives, (2) the development of relevant training approaches, and (3) the evaluation of training strategies. For Huemann et al., (2004) and Williams and Sengottuvelu (2016), training programs allow the project actor to take responsibility for acquiring the required skills and design his/ her professional development autonomously to boost his/ her employability.

In the project environment, training policy is considered an important management lever for human resources development in organizations (Huemann, 2010; Mir and Pinnington, 2014; Medina and Medina, 2014; Takey and Carvalho, 2015; Project Management Institute, 2017). The PBO aims to provide skilled workers with regular training (Demilliere, 2014) that needs to be managed throughout the life of a project (Zhang and Tian, 2012) and even after its dispersal (Huemann et al., 2007). Ramazani and Jergeas (2015) state that the training enables the preparation of project managers to be engaged within the context of real-life projects. Training within a project team provides added value in terms of commitment and specific skills and thus increases the project performance (Mir and Pinnington, 2014; Rue, 2014). Furthermore, Koskinen (2009) states that PBOs must continually acquire new necessary skills to manage their environment successfully. For Demiliere (2014) and Lappe and Spang (2014), organizations have to focus on developing and training their talent to achieve project goals so that the high costs are avoided at the end.

\section{Method}

\section{Data collection}

To answer our research question, we conducted a qualitative study. The data were collected primarily through semi-structured interviews with project managers. Indeed, the semi-structured interview leads the respondent to communicate numerous, detailed, and quality information on the research subject (Rousel and Wacheux, 2005), i.e., the relationship between the training policy and the project environment in the Tunisian context. The adoption of this type of interview allows the interviewees to respond as they wish but with "framed freedom" by the interviewer on well-defined themes.

To avoid the risks of bias arising from the interpretation of the primary data collected from the interviewees, we collected secondary data through the mobilization of 
documentary research and non-participant observation. These observations were carried out during our visits to the companies to examine the immediate environment of interviewees (Wacheux, 1996). We scrupulously took notes to record them for later analysis. Besides, the various documents collected from the companies for which the interviewees work (post-training evaluation forms, application letter for a training program, web training registration form, etc.) were the subject of a documentary analysis to enrich the study.

The choice of these different data collection methods (semi-structured interviews, documentary research, and non-participant observation) implies the prior preparation of an interview guide in which the interviewer prepares the questions to be discussed with the interviewees. The interview guide was built around the challenges faced by training policy in the project environment.

\section{Sample description}

The number of interviews was not determined previously. We stopped data collection when the last interview no longer engendered pertinent information. The final sample consisted of 31 Project Managers. We selected respondents who have useful information, are able to answer our research question, and of diverse gender, age, and years of experience. We interviewed 5 women (16.13\%) and 26 men $(83.87 \%)$. The average age of the sample was 39 years, ranging from 28 to 53 years. The interviewees had an average experience of 7 years as project managers.

\section{The conduct of interviews}

Interviews were conducted in the cities of Sfax and Tunis during the second half of 2016, following pre-arranged meetings with project managers. The interviews lasted on average 45 minutes. To guarantee the maximum collected information, we emphasized confidentiality, the climate of trust, and anonymity from the very beginning of each interview. We reassured the interviewees that this study was conducted for scientific purposes.

Of the 31 interviews carried out, 23 interviews were recorded using a Dictaphone. The recording allows a time-shifted listening which offers the possibility to extract some information that the interviewer was not aware of during the interview. However, 8 interviewees preferred not to record their verbal speeches for confidentiality reasons. As a result, we took notes from these unrecorded interviews. A total of 10 respondents were contacted again to clarify certain information. Subsequently, a transcript was made after each interview for a better interpretation of the collected data. Most of the interviews were conducted in French and Tunisian Arabic. Therefore, we called upon experts for the translation of the responses into English.

The triangulation of the data collection methods, the constant exchange throughout the study with a teacher-consultant, and the confirmation of the results obtained with the interviewees allowed us to reinforce the internal reliability of the research. In fact, 
meeting the internal reliability requirements has enabled us to produce rich interpretations faithful to what the interviewees said (Miles and Huberman, 2003).

\section{Data processing}

We opted for the content analysis method to exploit the collected information (Miles and Huberman, 2003). For these authors, content analysis is the most common method of qualitative data processing. It makes it possible to objectively exploit the data collected (words, expressions, paragraphs, etc.) from the verbal speeches of the interviewees and identify their meanings and significance. This method aims to simplify the representation of informational data. The breakdown of the responses collected from the semi-structured interviews was carried out manually, known as "paper-and-pencil" (Fenneteau, 2015). The identified categories were illustrated by meaningful verbatim (Thiétart et al., 2014). The fact that we did not use software during the content analysis is explained by the relatively modest volume of the collected data.

\section{Results and Discussion}

Recently, the demand for qualified and trained employees has grown rapidly as work methods and processes are constantly evolving within the project environment (Crawford, 2005). Several studies attach great importance to the training of project actors (Loi et al., 2014). Dillon and Taylor (2015) state that organizations make significant investments in training to increase projects' success rate.

"The training programs help project team members be more responsible and engaged in their work leading to greater efficiency in carrying out their activities" (Interviewee 10).

"A well-trained project manager can create an effective team that can deal with the vagaries of the project environment" (Interviewee 16).

\section{The role of training in skills development}

The results of the qualitative survey show that the training policy plays a crucial role in the development of the project actors' skills. The interviewed project managers believe that it is time to review how employees improve their skills in the face of increasing levels of complexity and uncertainty in the project environment. As a result, it is becoming increasingly important for organizations to strengthen their employees' skills through training programs.

"Project managers are required to develop their skills in order to properly direct their staff towards achieving the organization's objectives" (Interviewee 4).

"The training programs enable the development of reflective practitioners to learn, use, and adapt effectively to complex project activities" (Interviewee 24).

"The participation of junior project managers in training programs is strongly recommended before they become allowed to take on complex activities" (Interviewee 23). 
"Training is a realistic approach to bridging the gap between the required and acquired skills of my employees" (Interviewee 30).

"Managers must be fully aware of the importance of the training policy in maintaining and developing the skills of their staff" (Interviewee 12).

"The training programs help project team members be more responsible and engaged in their work leading to greater efficiency in carrying out their activities" (Interviewee 10).

"An experienced and well-trained workforce leads to increased productivity, better quality, and reduced costs" (Interviewee 14).

"Lack of skills poses major problems for project managers" (Interviewee 7).

"Skills development keeps employees focused on completing the tasks" (Interviewee 24).

"Personally, the new knowledge I have gained through the training programs has helped me a lot to finalize my activities" (Interviewee 28).

Most interviewees believe that PBOs should take the necessary measures to ensure that all human resources are sufficiently competent to perform their tasks. In this sense, the study of Imran and Zaki (2016) argues that companies should make efforts to develop effective training programs to get the most out of their human resources to avoid the high costs at the end of the project. Sarwar et al., (2016) state that PBOs must provide their employees with adequate training programs opportunities to improve their skills level. Buganza et al., (2013) argue that training policy plays a crucial role in developing and acquiring the skills of project managers. Likewise, Theeboom et al., (2014) stipulate that skills development keeps employees focused on the success of priority tasks. Furthermore, Fricke and Shenhar (2000) find that training is essential as it allows employees to have different roles and responsibilities in the project environment. It helps entry-level employees to master their skills and improve their performance at work (Zang et al., 2017). Abuazoom et al., (2017) state that continuing training aims to improve the capacities of the project team members to complete their tasks within established deadlines. In other words, training allows the employee to acquire new skills (González-Marcos et al., 2016; Medina and Medina, 2017; Dziekoński et al., 2017) that enable him/ her to plan and work autonomously (Marfuah and Panudju, 2016). According to the study of Ahadzie et al., (2009), developing and improving the professional skills of project managers through continuous training can positively impact their performance as well as the overall project outcome. Furthermore, Hunsberger $(2011$, p.31) states that "organizations must understand when they assign a resource to deliver a project, they are creating a project management position, and as such, they need to train their resources appropriately".

However, the project's success requires the development of various skills to ensure effective individual outcomes (Sumner and Powell, 2013; Silva de Araújo and Pedron, 2015). According to Barna (2013), training becomes necessary when project staff lacks technical or interpersonal skills. Technical skills refer to the ability to 
understand and apply the various tools and procedures related to project management (Keil et al., 2013). Conversely, interpersonal skills include, among others, decision making, delegation, and teamwork (Stevenson and Starkweather 2010). To develop employee's skills to a higher level, it is central to maintain a realistic balance between technical and interpersonal skills in the workplace. For Detsimas et al., (2016), training programs that address the development of both technical and interpersonal skills enable the company to become more flexible and respond quickly to changes in the project environment. These programs also help the managers to ensure the smooth operations of the projects (Imran and Zaki, 2016). The Study of El-Sabaa (2001) shows that project managers in the new technologies sector need to develop their interpersonal and technical skills to succeed in their careers. In other words, project managers are likely to be successful in dealing with the complexity of the work by applying technical and interpersonal skills. Furthermore, training often covers the technical skills (Pant and Baroudi, 2008) but neglects interpersonal skills that are more difficult to develop (Pant and Baroudi, 2008; Barna, 2013; Hanif and Tariq, 2014). However, some interviewees mentioned the excessive importance of technical skills in the content of training programs:

"What interests me in training programs is the development of the technical skills of my employees. I want them to do their work efficiently" (Interviewee 4).

"We have done a good job in terms of training. However, much remains to be done regarding the development of interpersonal skills. Comparing ourselves with other competitors, we are a long way off the mark" (Interviewee 16).

Several studies suggest that training programs in the project environment need to focus not only on technical skills but also on interpersonal ones (Müller and Turner, 2010; Starkweather and Stevenson, 2011; Ortiz-Marcos et al., 2013; Pournader et al., 2015). Similarly, Buganza et al., (2013) find that the most effective training program is based on interpersonal skills. This confirms their importance as a crucial factor in the projects' success. For this reason, many projects fail because project managers lack the necessary skills, such as communication and leadership (Müller and Turner, 2010). These skills are required to plan, organize, manage, budget, and monitor the progress of a project. Ferraris et al., (2017, p.11) argue that project actors should receive specific training that focuses on "project management capabilities, stakeholder analysis, systems thinking, time management, and coordination and delegating skills". For their part, Hanif and Tariq (2014, p.5) add that training programs need to add content related to "decision making, management of virtual teams, negotiation and conflict resolution, cultural aspects and communications management".

"In my opinion, the training programs I have recently attended lack the relational aspect. Managers need to train project team members to think analytically, collaborate, learn from each other, and be more creative. Obviously, this is much easier to talk about than to do" (Interviewee 19).

"It is important to maintain a realistic balance between technical and interpersonal skills to develop the skills of the project actor to a higher level" (Interviewee 28). 


\section{Lack of training due to time pressure and overwork.}

The results of the qualitative analysis show that some project managers interviewed do not have training programs in their organizations:

"Unfortunately, the overload of activities does not allow me to offer some training programs to my employees. It is true that training is essential to develop certain skills that are needed but the project duration is very short" (Interviewee 14).

"A training program is designed for several months. It is therefore difficult to find enough time to train employees due to the high pressure to deliver the project on time" (Interviewee 18).

"Training activities are a waste of time and can become an extra burden in our activities" (Interviewee 22).

Rogers (1990) argues that the lack of training in the planning process directly affects the project success. Similarly, Detsimas et al., (2016) indicate that there is no training available for certain project managers in the construction sector. Kappelman et al., (2007) state that project failure is attributed to lack of management support, particularly with a little trained project manager. For their part, Aramo-Immonen et al., (2011) argue that the lack of training in PBOs is due to the lack of time and a sense of heavy workload. These authors add that formal training is not considered a necessity in PBOs because managers are bombarded with urgent problems and delays. In the same vein, Hobday (2000) indicates PBOs create a work environment under pressure that leaves little room for formal training and a lack of incentives for human resource development. Indeed, Marfuah and Panudju (2016) argue that training activities are not only a waste of time but also become an additional burden for project managers. This happens due to training not being carried out in accordance with employees' needs, inappropriate timing and workplace, or other factors that may cause training to fail. Furthermore, Bredin (2008) states that high work intensity in PBOs has made it difficult to find time for formal skills development and training.

\section{Insufficient budget for training programs}

According to the majority of interviewees, the cost of employee training programs in the project environment is too high. This prevents project managers from planning training programs due to budget constraints:

"Two months ago, we bought new computer software to facilitate the resolution of some problems incurred in the project. However, most of my collaborators found it difficult to handle this software, which forced us to pay for training sessions to develop their technological skills. Of course, this training is not programmed in our budget" (Interviewee 15).

"Our company does not have sufficient financial resources to pay for my staff training" (Interviewee 20). 
"The training programs are important to maintain the skills of my collaborators, but they add additional expenses the project budget" (Interviewee 26).

These findings are consistent with those of several previous studies (Osmani et al., 2008; Khan and Rasheed, 2015; Alqahtani et al., 2015; Glăvan, 2015; Von Meding et al., 2016; Project Management Institute, 2017). For example, Khan and Rasheed (2015) find that training has a non-significant impact on the project success as the PBO tries to save the cost of training due to the limited budget. The study of Von Meding et al., (2016) shows that when the PBO does not have sufficient resources to develop the skills of its managers due to the limited budget, it becomes difficult to plan and prepare an adequate training program. Furthermore, Osmani et al., (2008) state that the lack of adequate training and skills on the part of employees is a primary cause of wasted money in construction projects. Similarly, Alqahtani et al., (2015) argue that organizations can spend much money to train their employees, but they find that sometimes the project outcome does not meet their expectations. According to the Project Management Institute (2017), training activities entail additional costs and expenses, while projects have to keep the lines due to the constraints of available budgets. This is also confirmed by the study of Glăvan (2015), which states that small and large companies do not invest more in the development of their employees because of the high expenses and time consumed.

\section{Conclusion}

To understand the different challenges of the training policy in the project environment, we conducted 31 semi-structured interviews with Tunisian project managers. The research showed that the training policy is a favorable context to skills development in the project environment. PBOs are called upon to promote the skills of their employees through training programs, including interpersonal and technical skills. The results also revealed that the temporary and unstable nature of the projects leaves little room for training due to time pressure, lack of budget, and work overload.

Our results present theoretical and managerial contributions. On a theoretical level, the present research work enriches the existing literature on the relationship between the training policy and the project environment. We synthesized all the studies that clarify this relationship. Furthermore, on a managerial level, this research provides managers with a rigorous presentation of the training policy in the project environment.

However, this work has several limitations: First, most interviewees carry out their activities only in two cities, namely Sfax and Tunis. It would be interesting to expand the sample by including project managers working in other regions of Tunisia. The second limitation is the small sample size: it would be interesting to conduct a similar study on a larger sample or even interview line managers and project directors to overcome this limitation. Another limitation inherent in the sample composition is the over-representation of men $(83.87 \%)$. It would be pertinent to interview more women project managers in the future. Finally, our research remains qualitative, 
requiring a further confirmatory factor analysis approach. Besides, a quantitative analysis could be carried out to reinforce the validity of the results obtained.

The limitations of this study highlight the need for some future research avenues. Therefore, it would be interesting first to measure the impact of the training policy on the performance of project teams through a quantitative study, second to explore the evolution of project managers' perceptions through a longitudinal study, and finally to extend the approach followed in other countries to contribute to improving the external validity and reliability of the results.

\section{References}

Abrantes, R., \& Figueiredo, J. (2013). Preparing project based organizations for Change. Procedia Technology, 9, 757-766.

Abuazoom, M. M. I., Hanafi, H. B., \& Ahmad, Z. Z. B. (2017). Influence of HRM practices on project performance: Conceptual framework. International Journal of Academic Research in Business and Social Sciences, 7(3), 47-54.

Afitep-Afnor, (2000). Dictionnaire de management de projet, 4th edition, Paris:Afnor.

Ahadzie, D. K., Proverbs, D. G., Olomolaiye, P. O., \& Ankrah, N. A. (2009). Competencies required by project managers for housing construction in Ghana. Engineering. Construction and Architectural Management, 16(4), 353-375.

Al Marri, K. (2014). ERP implementation in the project-based organizations of the construction industry. The Business and Management Review, 4(4), 1-13.

Alqahtani, F., Chinyio, E., Mushatat, S., \& Oloke, D. (2015). Factors effecting performance of projects: A conceptual framework. International Journal of Scientific \& Engineering Research, 6(4), 670-676.

Aramo-Immonen, H., Koskinen, K. U., \& Porkka, P.L. (2011). The significance of formal training in project-based companies. International Journal of Managing Projects in Business, 4(2), 257-273.

Awuzie, B., \& McDermott, P. (2016). A systems approach to assessing organizational viability in project based organizations. Built Environment Project and Asset Management, 6(3), 268-283.

Bakker, R. M. (2010). Taking stock of temporary organizational forms: A systematic review and research agenda. International Journal of Management Reviews, 12(4), 466-486.

Bakker, R. M., Boroş, S., Kenis, P., \& Oerlemans, L. A. (2013). It's only temporary: Time frame and the dynamics of creative project teams. British Journal of Management, 24(3), 383-397.

Bannerman, P. L. (2010). Risk implications of software project organization structures. Software Engineering Conference, 307-316.

Bardin, L. (2013). L'analyse de contenu. 2nd edition, Paris: Presses Universitaires de France.

Barna, L. (2013). Assessing the importance of project management soft competencies in an IT and telecommunication company. Theory, Methodology, Practice, 9(1), 17-21. 
Bartsch, V., Ebers, M., \& Maurer, I. (2013). Learning in project-based organizations: The role of project teams' social capital for overcoming barriers to learning. International Journal of Project Management, 31(2), 239-251.

Ben Tahar, O., \& Launaro, R. (2018). Le management de projet comme déterminant de l'innovation supplychain: Le cas d'une entreprise industrielle européenne. Logistique \& Management, 1-12.

Bocean, C. G. (2011). Project based organization: An integrated approach. Management et Marketing-Craiova, (2), 265-273.

Bredin, K. (2008). Human resource management in project-based organizations: Challenges, changes, and capabilities. Doctoral thesis in Management Sciences. Linköping: Linköping University.

Bredin, K., \& Söderlund, J. (2006). Perspectives on human resource management: An explorative study of the consequences of projectification in four firms. International Journal of Human Resources Development and Management, 6(1), 92-113.

Bresnen, M., Edelman, L., \& Newell, S. (2003). Social practices and the management of knowledge in project environments. International Journal of Project Management, 21(3), 157-166.

Buganza, T., Kalchschmidt, M., Bartezzaghi, E., \& Amabile, D. (2013). Measuring the impact of a major project management educational program: The PMP case in Finmeccanica. International Journal of Project Management, 31(2), 285298.

Chen, C. J., \& Huang, J. W. (2009). Strategic human resource practices and innovation performance: The mediating role of knowledge management capacity. Journal of Business Research, 62(1), 104-114.

Cheng, M. I., Dainty, A., \& Moore, D. (2006). Implementing a new performance management system within a project-based organization: A case study. International Journal of Productivity and Performance Management, 56(1), 60-75.

Choi, S., Cho, I., Han, S. H., Kwak, Y. H., \& Chih, Y. Y. (2018). Dynamic Capabilities of Project-Based Organization in Global Operations. Journal of Management in Engineering, 34 (5), 04018027.

Čiutienè, R., \& Neverauskas, B. (2012). The theoretical approach to project portfolio maturity management. Economics and Management, 16, 845-851.

Clarke, A. (1999). A practical use of key success factors to improve the effectiveness of project management. International Journal of Project Management, 17(3), 139-145.

Cook, C. R., \& Pritchard, C. L. (1998). Why project management ? In Cleland D. I. (Eds) Field Guide to Project Management, New York: Van Nostrand Reinhold, 22-33.

Crawford, L. (2005). Senior management perceptions of project management competence. International journal of project management, 23(1), 7-16.

Davenport, J. (2006). UK film companies: Project-based organizations lacking entrepreneurship and innovativeness? Creativity and Innovation Management, 15, 250- 257. 
DeFillippi, R., \& Lehrer, M. (2011). Temporary Modes of Project-Based Organization within Evolving Organizational Forms: Insights from Oticon's Experiment with the Spaghetti Organization. Project-Based Organizing and Strategic Management, 28, 61-82.

DeFillippi, R-J., \& Sydow, J. (2016). Project networks: Governance choices and paradoxical tensions. Project Management Journal, 47(5), 6-18.

Demilliere, A. S. (2014). The role of human resources in project management. Romanian Distribution Committee Magazine, 5(1), 36-40.

Detsimas, N., Coffey, V., Sadiqi, Z., \& Li, M. (2016). Workplace training and generic and technical skill development in the Australian construction industry. Journal of management development, 35(4), 486-504.

Dillon, S., \& Taylor, H. (2015). Employing grounded theory to uncover behavioral competencies of information technology project managers. Project Management Journal, 46(4), 90-104.

Dziekoński, K. (2017). Project managers' competencies model for construction industry in Poland. Procedia Engineering, 182, 174-181.

El-Sabaa, S. (2001). The skills and career path of an effective project manager. International journal of project management, 19(1), 1-7.

Fenneteau, H. (2015). Enquête: entretien et questionnaire. 3rd edition, Paris: Dunod.

Ferraris, A., Erhardt, N., \& Bresciani, S. (2017). Ambidextrous work in smart city project alliances: Unpacking the role of human resource management systems. The International Journal of Human Resource Management, 1-22.

Fricke, S. E., \& Shenbar, A. J. (2000). Managing multiple engineering projects in a manufacturing support environment. IEEE Transactions on engineering management, 47(2), 258-268.

Gajic, S., Sladic, A., \& Jovanovic, M. (2014). Project management methods for stimulating co-creation in IT projects. 6th International Conference on Mass Customization and Personalization in Central Europe, Novi Sad (Serbia).

Garel G., Giard V., \& Midler C. (2003). Management de projet et gestion des ressources humaines. In Allouche, J. (Eds) Encyclopédie des ressources humaines, Paris: Vuibert, 818-843.

Garel, G. (2003). Le management de projet, Paris: Editions La Découverte - (Repères).

Gemünden, H. G., Lehner, P., \& Kock, A. (2018). The project-oriented organization and its contribution to innovation. International Journal of Project Management, 36(1), 147-160.

Genest, B. A, \& Nguyen, T. H. (2002). Principes et techniques de la gestion de Projets. Laval: Les Éditions Sigma Delta.

Glăvan, O. R. (2015). Problems of structural funds projects' implementation in Romania and analysis of several good practices indicators. Project Management Development - Practice and Perspectives Fourth International Scientific Conference on Project Management in the Baltic Countries, Riga, University of Latvia.

González-Marcos, A., Alba-Elías, F., \& Ordieres-Meré, J. (2016). An analytical method for measuring competence in project management. British Journal of Educational Technology, 47(6), 1324-1339. 
Hanif, A., \& Tariq, S. (2014). An evaluation of personal and interpersonal competencies of project managers. Emerging Technologies (ICET), 2014 International Conference on IEEE.

Hedhili, M. A., \& Boudabbous, S. (2018). Organisation par projets et gestion des compétences: Application au cas tunisien. Doctoral Thesis in Management Science, Faculty of Economics and Management of Sfax, Tunisia.

Hobday, M. (2000). The project-based organization: An ideal form for managing complex products and systems ? Research policy, 29(7), 871-893.

Huemann, M. (2010). Considering human resource management when developing a project-oriented company: Case study of a telecommunication company. International Journal of Project Management. 28(4), 361-369.

Huemann, M., Keegan, A., \& Turner, J. R. (2007). Human resource management in the project-oriented company: A review. International Journal of Project Management, 25(3), 315-323.

Huemann, M., Turner, J. R., \& Keegan, A. (2004). Managing Human Resources in the Project-oriented Company. In Morris, P. W. G. (Eds) The Wiley guide to managing projects, New York: John Wiley and Sons, 1061-1086.

Hunsberger, K. (2011). The accidental project manager. PM Network, 25(8), 28-33.

Imran, A., \& Zaki, A. (2016). Impact of human capital practices on project success. Kuwait Chapter of the Arabian Journal of Business and Management Review, 5(6), 1-16.

Jamil, G. L., \& Magalhães, L. F. C. (2015). Perspectives for big data analysis for knowledge generation in project management contexts. In Jamil, G. L., Lopes, S. M., Silva, A. M., \& Ribeiro, F. (Eds) Handbook of research on effective project management research through the integration of knowledge and innovation. Hershey: IGI Global, 1-18.

Kappelman, L. A., McKeeman, R., \& Zhang, L. (2007). Early warning signs of IT project failure: The dominant dozen. Edpacs, 35(1), 1-10.

Keegan, A., Ringhofer, C., \& Huemann, M. (2018). Human resource management and project based organizing: Fertile ground, missed opportunities and prospects for closer connections. International Journal of Project Management, 36(1), 121-133.

Keil, M., Lee, H. K., \& Deng, T. (2013). Understanding the most critical skills for managing IT projects: A Delphi study of IT project managers. Information \& management, 50(7), 398-414.

Khan, A. S., \& Rasheed, F. (2015). Human resource management practices and project success, a moderating role of Islamic Work Ethics in Pakistani project-based organizations. International Journal of Project Management, 33(2), 435-445.

Kiznyte, J., Ciutiene, R., \& Dechange, A (2015). Applying cultural intelligence in international project management. Project Management Development Practice and Perspectives 4th International Scientific Conference on Project Management in the Baltic Countries, Riga: University of Latvia.

Koskinen, K. U. (2009). Project-based company's vital condition: Structural coupling: An autopoietic view. Knowledge and Process Management, 16(1), 13-22. 
Kujala, J., \& Ahola, T. (2005). The value of customer satisfaction surveys for projectbased organizations: Symbolic, technical, or none. International Journal of Project Management, 23 (5), 404-409.

Lappe, M., \& Spang, K. (2014). Investments in project management are profitable: A case study-based analysis of the relationship between the costs and benefits of project management. International Journal of Project Management, 32(4), 603-612.

Law, K. M., \& Chuah, K. B. (2004). Project-based action learning as learning approach in learning organisation: The theory and framework. Team Performance Management, 10(7-8), 178-186.

Leyrie, C. (2010). La politique dans les projets comme compétence collective: Proposition d'un modèle multi niveau et multidimensionnel. Congrès de l'AGRH.

Loi, T., Kubo, H., \& Shimoda, A. (2014). Process of human resource training for R\&D projects based on a project management phronesis acquisition model. Management Study, 2(4), 231-238.

Loosemore, M., Dainty, A., \& Lingard, H. (2003). Human resource management in construction projects: Strategic and operational approaches. Taylor et Francis

Loufrani-Fedida, S. (2006). Management des compétences et organisation par projets: Une mise en valeur de leur articulation (Analyse qualitative de quatre cas multi-sectoriels). Doctoral thesis in Management Sciences. Nice: Université de Nice-Sophia Antipolis.

Loufrani-Fedida, S. (2011). La gestion des ressources humaines au service de l'articulation entre management des compétences et organisation par projets. Revue de Gestion des Ressources Humaines, (1), 24-38.

Loufrani-Fedida, S. (2019). La gestion des ressources humaines à l'épreuve du management de projet: État des lieux et perspectives de recherche. @ GRH, (3), 9-45.

Loufrani-Fedida, S., \& Saglietto, L. (2016). Mechanisms for managing competencies in project-based organizations: An integrative multilevel analysis. Long Range Planning, 49(1), 72-89.

Lyons, P. (2009). Action theory and the training and performance application: Performance templates. Industrial and commercial training, 41(5), 270-279.

Małachowski, B., \& Korytkowski, P. (2016). Competence-based performance model of multi-skilled workers. Computers \& Industrial Engineering, 91, 165-177.

Marfuah, U., \& Panudju, A. T. (2016). Effectiveness of human resource development program at offshore project. International Journal of Scientific \& Technology Research, 4(8), 234-239.

Marfuah, U., \& Panudju, A. T. (2016). Effectiveness of human resource development program at offshore project. International Journal of Scientific \& Technology Research, 4(8), 234-239.

Medina, R., \& Medina, A. (2014). The project manager and the organisation's longterm competence goal. International Journal of Project Management, 32(8), 1459-1470. 
Medina, R., \& Medina, A. (2017). Managing competence and learning in knowledgeintensive, project-intensive organizations: A case study of a public organization. International Journal of Managing Projects in Business.

Melkonian, T., \& Picq, T. (2011). Building Project Capabilities in PBOs: Lessons from the French Special Forces, International Journal of Project Management, 29(4), 455-467.

Miles, M. B., \& Huberman, A. M. (2003). Analyse des données qualitatives. 2nd edition, Paris: De Boeck Supérieur.

Mir, F. A., \& Pinnington, A. H. (2014). Exploring the value of project management: Linking project management performance and project success. International Journal of Project Management, 32(2), 202-217.

Müller, R., \& Turner, J. R. (2010). Attitudes and leadership competences for project success. Baltic Journal of Management, 5(3), 307-329.

Munyeki, N., \& Were, S. (2017). Influence of transformational leadership on the performance of project based organizations: A case of International Livestock Research Institute. International Journal of Project Management, 1(3), 41-60.

Ng, Y. C., \& Siu, N. Y. (2004). Training and enterprise performance in transition: Evidence from China. The international journal of human resource management, 15(4-5), 878-894.

Ochieng, E., \& Price, A. D. (2009). Framework for managing multicultural project teams. Engineering, Construction and Architectural Management, 16(6), 527543.

Ortiz-Marcos, I., Cobo Benita, J. R., Aldeanueva, C. M., \& Colsa, Á. U. (2013). Competency training for managing international cooperation engineering projects. Project Management Journal, 44(2), 88-97.

Osmani, M., Glass, J., \& Price, A. D. (2008). Architects' perspectives on construction waste reduction by design. Waste management, 28(7), 1147-1158.

Othman, I., Idrus, A., \& Napiah, M. (2012). Human resource management in the construction of a sustainable development project: Towards successful completion. WIT Transactions on Ecology and the Environment, 162, 169180.

Pant, I., \& Baroudi, B. (2008). Project management education: The human skills imperative. International journal of project management, 26(2), 124-128.

Peltokorpi, V., \& Tsuyuki, E. (2006). Knowledge governance in a Japanese projectbased organization. Knowledge Management Research et Practice, 4(1), 3645.

Pournader, M., Tabassi, A. A., \& Baloh, P. (2015). A three-step design science approach to develop a novel human resource-planning framework in projects: The cases of construction projects in USA, Europe, and Iran. International journal of project management, 33(2), 419-434.

Prado, P., \& Sapsed, J. (2016). The anthropophagic organization: How innovations transcend the temporary in a project-based organization. Organization Studies, 37(12), 1793-1818.

Project Management Institute. (2017). Project Management Body of Knowledge (PMBOK® GUIDE). 6th Edition, 
Radović, S., \& Pejić, S. (2014). Capacity development for strategic public management. Serbian Project Management Journal, 4(1), 72-81.

Ramazani, J., \& Jergeas, G. (2015). Project managers and the journey from good to great: The benefits of investment in project management training and education. International Journal of Project Management, 33(1), 41-52.

Rogers, L. (1990). Project team training: A proven key to organizational teamwork and breakthrough in planning performance. Project Management Journal, 11(2), 9-17.

Roussel, P., \& Wacheux, F. (2005). Management des ressources humaines: Méthodes de recherche en sciences humaines et sociales. De Boeck Supérieur.

Rue, B. (2104), Project Management: Leading for Success, Friesen Press, Victoria, BC.

Salas, E., \& Cannon-Bowers, J. A. (2001). The science of training: A decade of progress. Annual review of psychology, 52(1), 471-499.

Samimi, E., \& Sydow, J. (2021). Human resource management in project-based organizations: Revisiting the permanency assumption. The International Journal of Human Resource Management, 32(1), 49-83.

Sarwar, H., Aftab, J., Sarwar, H., \& Shahid, A. (2016). Role of HRM in project success of project oriented organizations in Southern Punjab, Pakistan. Entrepreneurship and Innovation Management Journal, 4(3), 110121.

Shahzad, K., Bajwa, S. U., Ansted, R. B., \& Mamoon, D. (2016). Evaluating human resource management capacity for effective implementation of advanced metering infrastructure by electricity distribution companies in Pakistan. Utilities Policy, 41, 107-117.

Silva de Araújo, C. C. \& Pedron, C. D. (2015). IT project manager competencies and IT project success: A qualitative study. Organisational Project Management, 2(1). 53-75.

Söderlund, J. (2005). Developing project competence: Empirical regularities in competitive project operations. International Journal of Innovation Management, 9(4), 451-480.

Söderlund, J., \& Bredin, K. (2006). HRM in project-intensive firms: Changes and challenges. Human Resource Management, 45(2), 249-265.

Starkweather, J. A., \& Stevenson, D. H. (2011). PMP® certification as a core competency: Necessary but not sufficient. Project Management Journal, 42(1), 31-41.

Stevenson, D. H., \& Starkweather, J. A. (2010). PM critical competency index: IT execs prefer soft skills. International Journal of Project Management, 28(7), 663671.

Sumner, M., \& Powell, A. (2013). What project management competencies are Important to Job Success? Americas Conference on Information Systems AMCIS, Chicago.

Tabassi, A. A., \& Bakar, A. A. (2009). Training, motivation, and performance: The case of human resource management in construction projects in Mashhad, Iran. International Journal of Project Management, 27(5), 471-480.

Tabassi, A. A., Ramli, M., \& Bakar, A. H. A. (2012). Effects of training and motivation practices on teamwork improvement and task efficiency: The case of 
construction firms. International Journal of Project Management, 30(2), 213224.

Takey, S. M., \& De Carvalho, M. M. (2015). Competency mapping in project management: An action research study in an engineering company. International Journal of Project Management, 33(4), 784-796.

Theeboom, T., Beersma, B., \& Van Vianen, A. E. (2014). Does coaching work? A metaanalysis on the effects of coaching on individual level outcomes in an organizational context. The Journal of Positive Psychology, 9(1), 1-18.

Thiétart, R. A. (2014). Méthodes de recherche en management. 4th edition, Paris: Dunod.

Todorović, M., Mitrović, Z., \& Bjelica, D. (2013). Measuring project success in projectoriented organizations. Journal for Theory and Practice Management, 68, 41-48.

Turner, J. R. (1993). The Handbook of Project-Based Management, London: McGrawHill Publishing

Turner, J. R. (2016). Gower handbook of project management. Gower Publishing.

Turner, J. R., \& Keegan, A. (2000). The management of operations in the projectbased organization. Journal of Change Management, 1(2), 131-148.

Turner, J. R., Huemann, M., \& Keegan, A. (2008). Human resource management in the project-oriented organization: Employee well-being and ethical treatment. International Journal of Project Management, 26(5), 577-585.

Von Meding, J., Wong, J., Kanjanabootra, S., \& Tafti, M. T. (2016). Competence-based system development for post-disaster project management. Disaster prevention and management, 25(3), 375-394.

Wacheux, F. (1996). Méthodes qualitatives de recherches en gestion. Paris: Economica.

Williams, J., \& Sengottuvelu, C. (2016). A study of HR practices on aviation software project outcomes. International Academic Research Journal of Economics and Finance, 4(1). 10-18.

Zakaria, N. (2013). Enchancing organizational performance of Malaysian SMEs through human resource management (HRM) practices and organizational innovative capability: A proposed framework. 3rd International Conference on Management, Hydro Hotel, Penang, Malaysia

Zarifian, P. (1988). L'émergence du modèle de la compétence. In Stankiewicz, F. (Eds) Les stratégies d'entreprises face aux ressources humaines. Paris: Editions Economica, 77- 82.

Zhang, J., Yu, P. S., \& Lv, Y. (2017). Enterprise employee training via project team formation. In Proceedings of the Tenth ACM International Conference on Web Search and Data Mining, 3-12.

Zhang, W. M., \& Tian, C. (2012). Brief analysis of human resource management in project management. Applied Mechanics and Materials, 174, 2840-2843.

Zohrevandi, S., \& Rouzbeh A. M. (2014). The effects of the project management office on companies performance: A case study on a project-oriented company. International Journal of Business and Economics, 5(1), 87-100. 